\section{maxnunsumus ANALISIS DE COYUNTURA}

Revista Venezolana de Análisis de Coyuntura ISSN: 1315-3617

coyuntura@cantv.net

Universidad Central de Venezuela Venezuela

Arestis, Philip; Ferrari-Filho, Fernando; Paula, Luiz Fernando de; Sawyer, Malcolm

The euro and the EMU: lessons for Mercosur

Revista Venezolana de Análisis de Coyuntura, vol. IX, núm. 1, enero-junio, 2003, pp. 229-252

Universidad Central de Venezuela

Caracas, Venezuela

Available in: http://www.redalyc.org/articulo.oa?id=36490109

How to cite

Complete issue

- More information about this article

Journal's homepage in redalyc.org

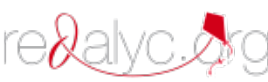

Scientific Information System Network of Scientific Journals from Latin America, the Caribbean, Spain and Portugal Non-profit academic project, developed under the open access initiative 


\title{
THE EURO AND THE EMU: LESSONS FOR MERCOSUR
}

\author{
Philip Arestis \\ SOUTH BANK UNIVERSITY \\ LONDON
}

\section{Luiz Fernando de Paula \\ STATE UNIVERSITY OF RIO DE JANEIRO AND CNPQ}

\author{
Fernando Ferrari-Filho \\ FEDERAL UNIVERSITY OF RIO \\ GRANDE DO SUL AND CNPQ \\ Malcolm Sawyer \\ UNIVERSITY OF LEEDS
}

\begin{abstract}
Abstracs:
Academic debate in South America favours a MERCOSUR monetary union based on the euro and the Economic and Monetary Union (EMU), and inspired by the theory of Optimal Currency Area (OCA). This paper aims to discuss whether the adoption of a single currency in the EMU mould of monetary union, is appropriate and feasible for the MERCOSUR. Three lessons are derived for MERCOSUR from the euro and the EMU experience: the adoption of the EMU model of monetary union would imply deflationary policies; there is the dilemma of sequencing between political union and economic integration; and the necessity of accounting seriously the concerns of the OCA literature. The paper also shows that there is no evidence that macroeconomic convergence is evident in MERCOSUR, since the area only minimally achieved some basic criteria defined by the OCA literature.

Key words: Economic and monetary union, Mercosur, optimum currency area.
\end{abstract}

\section{INTRODUCTION}

In 1991, the Asunción Treaty, signed by Argentina, Brazil, Paraguay and Uruguay, created The Common Market of the South (thereafter MERCOSUR). At that time, MERCOSUR was created to be only a Customs Union that came into effect on 1 January, 1995. The MERCOSUR experience has been characterised by economic turbulences: in January 1999, the Brazilian currency, real, was devaluated and, as a result, it brought some spillover effects in the MERCOSUR area; recently, more specifically, at the end of 2001 and beginning of 2002, the

* This paper was presented to the Workshop entitled "Towards Macroeconomic Convergence in MERCOSUR? Lessons from the European Monetary Union", organised by the Centre for Brazilian Studies and Argentine Studies Programme, University of Oxford, and held at St Antony's College, University of Oxford, 12 June 2001. This paper was updated, in February 2002, to account for the turbulence in Argentina. 
economic, political and institutional crises in Argentina, characterized by the collapse of the Convertibility Plan ${ }^{1}$ - that is to say, the devaluation of Argentine currency -, the default of Argentine foreign debt and tensions among governments and socio-economic actors ${ }^{2}$, have caused further macroeconomic instability to the MERCOSUR countries. This raises the question of whether a monetary union in this area is the way forward. In 1998 the annual regional summit of MERCOSUR actually indicated the possibility of creating a single currency. In December 2000, macroeconomic convergence criteria that included inflation rates, fiscal deficits, public sector debt and balance of payments, were suggested as a way forward ${ }^{3}$. Academic debate in South America favours a MERCOSUR monetary union based on the European Economic and Monetary Union (EMU), and inspired by the theory of Optimal Currency Area (OCA) - Edwards, 1998, Rigolon and Giambiagi, 1999, Giambiagi, 1999, is a representative sample.

The EMU was founded in January 1999 along with the European Central Bank (ECB), and the launch of the single currency (euro). The euro was established for financial transactions with the exchange rates between those national currencies, which will be absorbed by the euro eventually, fixed (to 6 significant figures). The euro will replace the component national currencies for all transactions in the first two months of 2002 (the precise dates and arrangements varying between countries). The value of the euro has declined through most of the period of its existence from an initial value vis-à-vis the dollar of $\$ 1.18$, to parity with the dollar in December 1999, an all-time low in November 2000 of $\$ 0.82$, and to around $\$ 0.87$ at the time of revising this paper, February 2002 . We have explored the explanations for that decline elsewhere (Arestis et al, 2001a, 2001b).

The EMU constitutes a change in the economic, social and political spheres of Europe. Inevitably, it has been the subject of intense debate. The single currency has served to concentrate many diverse aspects of the debate around one question: is the euro in the interests of Europe? And for the purposes of this pa-

\footnotetext{
${ }^{1}$ As is well-known, the Convertibility Plan, implemented in April 1991, established by law a one-to-one parity between the Argentine currency, the peso, and the U.S.dollar. It also required that the currency in circulation would be equal to the available gold and currency reserves. As a result, the Central Bank of Argentina became a "currency board". For an analysis of the Convertibility Plan, see Fanelli et al (1996).

${ }^{2}$ It is important to say that, from December 2001 to January 2002, after the former president Fernando de la Rua was forced to resign due to his own mistakes, Argentina had three different presidents.

${ }^{3}$ By the way, it was called a "Little Maastricht" for the MERCOSUR.
} 
per: is the euro experiment a good example for MERCOSUR to adopt? We argue that the economic impact of the euro, and its accompanying monetary institutions, is likely to be deflationary and destabilising. We do not, however, argue that the project of a single European currency is inherently flawed, but rather that the institutional and policy arrangements within which it is embedded are flawed. On the contrary, we have proposed elsewhere (Arestis, McCauley and Sawyer, 2001) a Keynesian alternative to the economic policies and institutions that currently surround the euro. In this way, we argue that the broad question is not whether to be 'for' or 'against' the euro per se, but to get the 'right' institutional framework and policy for the achievement of high employment levels throughout the Union. Lessons based on the euro and the EMU approach, will be derived for MERCOSUR in this paper.

We proceed in the section that follows to examine the institutional structure of the euro experiment before we turn our attention to its theoretical underpinnings. The two sections that follow discuss the problematic nature of both the institutional arrangements and the theoretical framework, respectively, upon which they are based. We then concentrate on the lessons for MERCOSUR that may be drawn from the EMU experience. The realities of the MERCOSUR proposed arrangements is the focus of the penultimate section. $A$ final section summarises the argument and concludes.

\section{INSTITUTIONAL UNDERPINNINGS}

The euro was adopted in January 1999 with the member currencies locked together from that point, and with the intention that the euro is used as the sole currency in the participating countries from early 2002. Criteria were set down under the Maastricht Treaty that were intended to be met by those seeking to join the euro (see Arestis, Brown and Sawyer, 2001). The convergence criteria were in nominal terms with no mention of real convergence or even of business cycle convergence. They included a budget deficit and a government debt criteria designed to establish 'fiscal responsibility' in the eyes of the financial markets and had no underlying rationale. The independence of the ECB, and that of national central banks, was also part of the list of these criteria. In terms of countries meeting the criteria, it must be said that with the exception of the inflation rate and the interest rate, they were not met as comfortably as it might have appeared initially. In fact a great deal of 'fudging' took place, and that may have added to the subsequent weakness of the euro. In the event, eleven countries out of the 15 member countries of the EU were deemed to have met both these criteria and joined the EMU (Greece was not included initially, but in January 2001 was deemed to have met the criteria and as such is now a member of the EMU). 
The institutional arrangements accompanying the euro involve the creation of an 'independent' (of political control) European System of Central Banks (ESCB) with its operating arm, the ECB and the national central banks, which is given the sole policy objective of price stability, defined as a year-on-year increase in the Harmonised Index of Consumer Prices (HICP) for the euro area of below 2 per cent over the medium term. The dominant feature of the ECB's institutional structure is the complete separation between the monetary authorities (in the form of the Central Bank) and the fiscal authorities (in the shape of the national governments comprising the EMU), where the latter are constrained to keep their budget deficit below 3 per cent according to the Stability and Growth Pact, noting that this implies a budget position in balance or slight surplus over the course of the business cycle. It follows that there can be little co-ordination of monetary and fiscal policy. The eurosystem is perhaps unique in having a 'high level' monetary authority (the ECB) and in effect no 'high level' fiscal authority with fiscal policy residing at the national level (albeit constrained by the Stability and Growth Pact). There cannot be any substantive co-ordination of monetary and fiscal policies in these circumstances, and there is a sense in which the monetary authority has the last word in that interest rates are set frequently and can be adjusted to seek to offset any fiscal policy. It is also the case that the independence of the ECB and the national central banks places heavy constraints on any coordination of fiscal and monetary policy. For example, 'neither the ECB, nor a national central bank, nor any member of their decision making bodies shall seek or take instructions from Community institutions or bodies, from any government of a Member States or from any other body' (Article 7 of The Statute of the European System of Central Banks and of the European Central Bank). Any strict interpretation of this edict would rule out any attempt at co-ordination of monetary and fiscal policies. Indeed the primacy of monetary policy over fiscal policy is guaranteed because of the institutional structure and rules of the ESCB.

The Stability and Growth Pact, which accompanied the introduction of a single currency, governs the economic policies of the member countries which have joined the single currency and strongly constrain the policies of those who aspire to join. It is an important dimension of the institutional framework of the EMU, and as such we need to discuss it at some length.

\section{Stability and Growth Pact}

The Stability and Growth Pact, alongside the Maastricht Treaty, creates four rules for economic policy. The four rules are that the ECB was granted independence from political influence; the introduction of the 'no-bail out of national government deficits' rule; the prohibition of monetary financing of government 
deficits; and that member states must avoid 'excessive' deficits (defined as more than 3 per cent of GDP).

A government which aims to avoid an 'excessive' budget deficit of more than 3 per cent of GDP would have to ensure that the 3 per cent limit is not breached during economic slowdown; and hence that the average deficit during the course of the business cycle would have to be much lower than 3 per cent. A country's budgetary data become available for the Commission to scrutinise on 1 March each year when the stability programmes are submitted. Each programme contains information about the paths of the ratios of budget deficit to GDP and national debt to GDP. The Council (ECOFIN) examines the stability reports and delivers an opinion on a recommendation by the Commission (within two months of the reports submission). If the stability programme reveals that a country is significantly diverging from its medium-term budgetary objective, then the council recommends that the stability programme is strengthened. If the situation persists then the member state has been judged to have breached the reference values. The Pact details 'escape' clauses which allows a member state that has an excessive deficit to avoid sanction. If there is an economic downturn and output has fallen by more than 2 per cent, then the member state escapes sanction automatically but the deficit should be corrected once the recession has finished. If output falls between 0.75 and 2 per cent then the Council can use discretion when making a decision on an 'excessive' deficit, other factors are taken into account such as the abruptness of the downturn, the accumulated loss of output relative to past trends and whether the government deficit exceeds government investment expenditure.

If a country is found to have breached the reference values, then it has four months to introduce the corrective measures suggested by the Council. If the country follows the Council's recommendations, then the 'excessive' deficit can continue, but the budget deficit must be corrected within a year following its identification. A country, which chooses not to introduce corrective measures, is subject to a range of sanctions (Article 104c(11)), at least one or more must be imposed, of which one must be in the form of a non-interest bearing deposit lodged by the national government. In this instance, it falls upon EMU members, excluding the member country under consideration, to reach a decision on sanctions. The non-interest bearing deposit consists of a fixed component $(0.2$ per cent of GDP), and a variable component, (one tenth of the difference between the deficit ratio and the 3 per cent reference value). If the budget deficit is not corrected within two years, the deposit is forfeited and becomes a fine, whereas if the deficit is corrected within two years the deposit is returned and the penalty becomes the foregone interest. 
This system of financial penalties for breaches of the budget deficit criterion, implies that deflationary fiscal policies continue, and indeed intensify as those countries which just met the 3 per cent requirement in conditions of cyclical upswing have to tighten the fiscal stance to meet the 3 per cent requirement in times of cyclical downswing especially. It was indicated above that a clause was inserted into the Stability and Growth Pact, which allows a country to have a larger deficit in the face of recession. However, even this formal recognition that automatic stabilisers and active fiscal policy could be hampered may not be sufficient to prevent the Stability and Growth Pact operating to exacerbate recessions.

The overall conclusion of the discussion in this section is that a number of problems can be identified in view of the EMU and the euro institutional arrangements. For the purposes of our study two of these can be highlighted. The first is that fiscal policy is in effect absent (other than, of course, directives to member-states emanating from the Stability and Growth Pact); monetary policy is given priority over fiscal policy, and co-ordination of fiscal and monetary policies is prohibited. At both national and EU level, the use of fiscal policy is heavily constrained by the Stability and Growth Pact. The second is that the institutional set up produces a certain bias for deflationary tendencies. The experience since 1999 in terms of the ECB monetary policy performance, especially the reluctance of the ECB to reduce interest rates (more recently such reduction has taken place only after enormous pressures by the US and other national governments, the IMF and World Bank, and other international fora) clearly testify to the bias just mentioned. Further examples may be mentioned. The recent condemnation of Ireland for cutting taxes and raising public expenditure when output was above trend, criticisms of Britain, even though outside of the eurozone, for proposing public expenditure increases above the trend rate of growth of output point to a general deflationary bias in the operation of the Stability and Growth Pact. It also means that governments are put under pressure to raise taxes and/or cut government spending under recessionary circumstances, which exacerbates the downturn. This is illustrated by the recent (April 2001) recommendation to the British government (who are not formally governed by the Stability and Growth Pact) that in the event of a downturn in 2002, public expenditure should be reduced (below planned levels) to maintain the public expenditure to GDP ratio. It, thus, follows that macroeconomic policy at the EMU level has been designed to operate in a restrictive manner. ECB pursues extremely cautionary rules, presumably in its attempt to gain 'credibility' in the financial markets at the cost of any other objectives. A serious implication at this juncture is that with the US slowdown, which threatens to produce a world recession, EMU policy could potentially help to avoid it. The ECB policy stance at the moment does not appear to be geared to this objective. 


\section{THEORETICAL UNDERPINNINGS}

The theoretical underpinnings of the EMU institutional structure appears to be based on what we have elsewhere termed new monetarism (Arestis and Sawyer, 1998b). The essential features of new monetarism are:

(i) Politicians in particular, and the democratic process in general, cannot be trusted with economic policy formulation with a tendency to make decisions which have stimulating short-term effects (reducing unemployment) but which are detrimental in the longer term (notably a rise in inflation). In contrast, experts in the form of central bankers are not subject to political pressures and can thus take a longer-term perspective. The logic underpinning this reasoning mirrors that found in the rules versus discretion debate. Policy makers' scope for using discretion should be curtailed and the possibility of negative spillovers from irresponsible fiscal policy must be reduced within the eurosystem. Consequently, fiscal policy is permanently constrained by the Stability and Growth Pact and monetary policy is removed from national and political authorities and placed with the ECB.

(ii) Inflation is a monetary phenomenon and can be controlled through monetary policy. Although money supply is difficult to control directly, it is nonetheless useful as a reference magnitude. The ECB can set the key interest rate to influence monetary conditions, which in turn influence the future rate of inflation.

(iii) A 'two-pillar' monetary strategy is actually pursued. This may be briefly summarised: the 'first pillar' is a commitment to analyse monetary developments for the information they contain about future price developments. This is the quantitative reference value for monetary growth $(4.5 \%$ of $\mathrm{M} 3)$ referred to in the text. The 'second pillar' is a broadly based assessment of the outlook of price developments and the risks to price stability. This broad range of indicators includes the euro exchange rate, labour market indicators (such as wages and unit labour costs), fiscal policy indicators, financial market indicators (such as asset prices), etc.

(iv) The level of unemployment fluctuates around a supply-side determined equilibrium rate of unemployment, generally labelled the NAIRU (nonaccelerating inflation rate of unemployment). The level of the NAIRU may be favourably affected by a 'flexible' labour market, but is unaffected by the level of aggregate demand or by productive capacity.

(v) Fiscal policy is impotent in terms of its impact on real variables and as such it should be subordinate to monetary policy in controlling inflation. It is recognised, though, that the government budget position will fluctuate during the 
course of the business cycle but in the context of an essentially passive fiscal policy. The main feature of the Stability and Growth Pact is a requirement that the national budget deficit does not exceed 3 per cent of GDP, and failure to meet that requirement could lead to a series of fines depending on the degree to which the deficit exceeds 3 per cent (as further discussed below). Non-euro members are also required to exercise similar fiscal control through convergence programmes, though they are not subject to excessive deficit penalties.

The economic policy implications that lie behind this type of analysis is one in which macroeconomic demand conditions, including monetary and fiscal policies, cannot affect the (equilibrium) level of unemployment of labour, and in more general terms the level of economic activity. The level of unemployment and of economic activity is viewed as solely a supply-side phenomenon. An important problematic aspect of this policy framework is the symmetry or otherwise of shocks. Given the one-instrument only nature of monetary policy within the eurosystem, the extent of asymmetrical shocks becomes paramount. If shocks are indeed asymmetrical the one-policy framework cannot tackle effectively even the one-target objective of price stability. From the perspective of the business cycle, it could be argued that Ireland with output above trend to the extent of over 2.5 per cent of GDP, and Italy with output below trend to the extent of 2.5 per cent of GDP, require quite different macroeconomic policies. The optimists would tend to believe that the introduction of the euro and the continuing effects of the single market, would lead to further integration between the national economies. This integration could then be reflected in some convergence between national business cycles and a reduction in the extent of asymmetric shocks (that is shocks that impact on some economies but not on others). If there were full integration between the national economies, then a unified economic policy would be appropriate though we would argue that a single policy instrument such as interest rates is not sufficient to achieve multiple objectives.

\section{POLITICAL UNION AND/OR ECONOMIC CONVERGENCE?}

One might have expected that the formation of the EMU, encompassing twelve politically independent countries each with their own currencies prior to the Union, would be much influenced by economic convergence and political union considerations. It is the purpose of this section to demonstrate that neither of these considerations had been influential in creating and shaping the EMU and the euro. 


\section{Political Union}

Table 1 divides monetary unions into a number of categories. The first is that category that includes those unions that survive with political union as well. Political union ensures the success of the monetary union. The examples referred to in Table 1 are obvious enough. The second category includes unions of small countries that have survived without political union. These unions have survived because of economic convergence with varying degrees of success. The third category is where the survival of the union depends crucially on the political system. As soon as the political bond disappears, so does the monetary union. The fourth category is an obvious one: once economic links collapse, the union disappears. The fifth category contains temporary monetary unions. They survive for some time without political union but eventually collapse when they are subjected to severe shocks (in the example of Table 1, the suspension of the gold standard at the beginning of World War I that led to volatility in real exchange rates, and the inflationary pressures following the cessation of hostilities, were the main causes). A sixth category represents currency pegs and other systems. This is an example that demonstrates the importance of flexibility. This is particularly pertinent when currency systems attempt to bind together economies whose cycles and structures are significantly different.

There are two important lessons that can be derived from this short excursion into the history of monetary unions. The first is that political union appears to be an extremely important prerequisite for a monetary union to survive. Monetary unions last for some time but eventually they must become a political union to survive. The second is that economic convergence when political union is not present, is paramount both for the survival of a monetary union of small independent states.

A belief that a market economy will function effectively without government intervention and redistribution would obviate any need for economic policies within the eurozone. The eurozone begins with considerable economic disparities. The views that either they will be eliminated through a process of market competition or that such disparities are politically sustainable would lead to the view that there is little requirement for an effective political union. By effective political union here we would involve significant EU level taxation, social security and public expenditure programmes. We leave open the question as to whether that would entail a formal political union within a federal state. We would argue that the effective operation of a market economy involves government intervention of that form. A common social security system would enhance labour mobility as well as involve elements of redistribution. A substantive fiscal policy would likewise aid economic integration but would involve significant fiscal transfers between regions and between countries. 
The present arrangements governing the euro do not involve mechanisms for the reduction of the disparities of unemployment and GDP per head. The disparities of unemployment inevitably undermine the achievement of high levels of employment across the eurozone. When some regions are experiencing low unemployment and high rates of capacity utilisation, others remain with high unemployment. Inflation pressures, actual or perceived, in the low unemployment regions will lead high interest rates and attempts to slow down the eurozone economy. A monetary union involves the imposition of a common currency across a number of nations through the requirement that the common currency is the only legal tender within the nations involved. In that trivial sense, a monetary union involves a degree of political agreement, if not political union. There is also the obvious requirement for a central bank for the monetary union, and in an era of dominance of monetary policy over fiscal policy, that central bank becomes the effective macro-economic policy maker. Any requirements for an effective fiscal policy across the monetary union which would be redistributive across time and space pointing in the direction of the emergence of a fiscal authority at the level of the monetary union. Further requirements such as measures to enhance trade or for a common social security system to enhance labour mobility, again point in the direction of policies being exercised at the level of the monetary union. It could be said that it is feasible that such policies can be introduced through the construction of institutions at the level of the monetary union without formal political union. But in a number of respects if there were to be fiscal policy, social security policy etc., at the level of the monetary union, it comes close to being a political union. We would suggest, though, that a monetary union requires considerable central government to operate fiscal and social security policies across the eurozone.

\section{Economic Convergence}

The second conclusion reached from our discussion of Table 1 is that of economic convergence. Although this conclusion concerns small states the argument can easily be generalised. It might be expected that any monetary union encompassing a number of politically independent countries, each with their own currencies prior to the union, would be much influenced by Optimal Currency Area (OCA) considerations. We suggest, though, that OCA considerations had virtually no impact on the decision to introduce a single European currency nor on the conditions governing which countries were to be members. It ought to be noted, though, that the single currency was preceded by the Single European Act that created a single market which involved more than just free trade in that it sought to bring in common standards for goods and services, reduction of 'invisible' trade barriers, and mobility (as least legally) of labour and capital. There were also, of course, the Maastricht criteria as explored above, but they related 
to convergence in nominal variables at a particular point in time, and made no reference to convergence in real variables (whether in terms of levels such as GDP per head or rates of change and position within the business cycle). Nor was there any reference to what could be termed structural convergence in terms of institutional and organisational arrangement.

The relevant literature suggests three conditions for an 'Optimal Currency Area' (Mundell, 1961; see, also, McKinnon, 1963, and Kenen, 1969); (a) factor mobility and openness of markets; (b) relative price flexibility; and (c) fiscal transfers within the monetary union. It would be desirable for a single currency to be used in an economic area within which there is openness of goods markets and mobility of factors of production (labour, capital) as the mobility of factors is seen as one way in which adjustment is made to differences in economic performance. Further, member economies should share similar inflationary tendencies since a common currency imposes a common inflation rate. The Single European Act of 1986 and the implementation of the single European market by the end of 1992 were steps in seeking to ensure the mobility of goods and services and of capital within the European Union. But it is well-known that effective labour mobility with the EU remains low, especially by comparison with the USA, despite the large differences in real wages and unemployment rates across the EU. Price flexibility (in terms of relative prices across countries) remains low. The differences in labour market institutions, notably over wage determination mean that there are different inflationary tendencies and different responses to economic shocks. The convergence criteria ensured a convergence of inflation rates which is not the same as convergence of inflationary mechanisms and tendencies. Indeed, similar rates of inflation across the eurozone countries in 1998 (the relevant year for the application of the convergence criteria) were accompanied by widely differing rates of unemployment from around 4 per cent in the case of Austria and the Netherlands to 17 per cent in the case of Spain (and the difference in unemployment between regions was much more marked from 3 per cent in the Oberösterreich region of Austria to 32 per cent in the Anduluscia region of Spain and nearly 37 per cent in Reunion, France (these figures refer to 1997). The calculated output gap, as a sign of the stage of the business cycle, varied (according to the OECD measure) from over +2 per cent in Ireland to -2 per cent in Italy (and there was a slight widening of the differences in 1999). Fiscal transfers are hardly in evidence and there is no possibility of the EU budget operating as a stabiliser. There is currently no mechanism for the operation of an EU level fiscal policy that could have stabilising effects (as an automatic stabiliser) over time nor which has any significant redistributive element across economic regions.

The optimists would tend to believe that the continuing effects of the single European market and the introduction of the euro will lead to further integration 
between the national economies. This integration could then be reflected in some convergence between national business cycles and (perhaps) some reduction in the extent of asymmetric shocks that impact on some countries but not on others. There could, in the fullness of time, be increased mobility of labour. But there seems little prospects of EU wide measures such as a common social security policy which would enhance the mobility of labour. In any case, we have demonstrated elsewhere (Arestis et al, 2001b) that since the introduction of the euro in January 1999, there is no evidence that economic convergence has taken place or is in sight of materialising.

This brief discussion indicates to us that OCA considerations appear to have played little role in the formation of the eurozone. Further, if the OCA literature is correct, then the eurozone would appear not to be an optimal currency area. Some of the departures of the eurozone from an OCA arise from policy decisions (notably the absence of a EU fiscal policy) whereas others (notably lack of labour mobility) are more deeply embedded and some attempts have been made to address them (e.g. development of transferability of qualifications between countries). But to say that the eurozone is not optimal is not the same as saying that the eurozone is not better than the continuation of national currencies. However, we would argue that it is still the case that the criteria proposed by the OCA literature still have some relevance in judging whether the introduction of the euro is an improvement. The point remains that the OCA literature has been ignored.

\section{LESSONS FOR MERCOSUR}

In this paper we have touched upon the most important problematic issues arising from the creation of the EMU. The implications of these issues for moves towards some form of monetary union amongst the MERCOSUR countries may now be summarised.

Our discussion of the OCA literature enables us to conclude that decisions on the EMU have not accounted for the concerns of the OCA literature. In the formation of the eurozone there seems little possibility of significant labour mobility or fiscal policy being used in this way. We see this as a considerable weakness in the formation of EMU, and would argue that any eventual MERCOSUR monetary union should pay attention to these issues. A related lesson relates to the question of whether a sustainable monetary union requires a considerable degree of political integration, and eventually a political union. We have attempted to supply an answer based merely on the history of monetary unions. Our answer on this basis is positive. We would also suggest that in the absence of a political union, a minimum of a pan-union fiscal policy and a social security system operating at the level of the monetary union, are desperately required. The 
diversity of economic performance, institutional arrangements and beliefs on economic policy and the operation of market economies are all further difficulties in the construction of a monetary union.

The creation of a monetary union obviously creates a union level monetary policy. It is widely recognised that monetary policy imposes a single policy applying across a diverse set of economic regions. A particular monetary policy may be appropriate for the position of some economies but not for others given their position in the business cycle and the responsiveness of their economies to monetary policy, and the monetary policy is more likely to favour the politically strongest (even when operated by an 'independent' central bank). Further, monetary policy is constructed to deal with demand induced inflation with interest rates raised (lowered) in response to inflation (actual or expected) above (below) the target rate, though we would doubt the effectiveness of monetary policy to significantly influence aggregate demand. But monetary policy cannot deal with other forms of inflation (e.g. cost push inflation) nor with situations in which there is high (or rising) inflation combined with low (or falling) levels of economic activity. The monetary union requires a further set of policy instruments including fiscal policy.

In the section that follows, we discuss the degree of severity of the 'lessons' just identified for MERCOSUR. We take the view that the 'lessons' in terms of a union-level monetary policy and that of a political union are serious considerations that would have to be resolved before any move towards a monetary union MERCOSUR. This is actually reminiscent of the debates over financial liberalisation in terms of the concerns expressed over the sequencing of institutional and policy changes. It could be argued that a similar concern should arise with monetary union, namely whether monetary union should precede economic and political integration or come after considerable integration. Unlike the current advocates of the formation of the European single currency who hold a different view, we are of the opinion that monetary union should come after other economic and social integration has materialised. This is probably the most important question arising from the European experience that we see as of particular relevance for monetary union and dollarisation in the case of MERCOSUR. As for the realities relating to the OCA possibility, we may refer to the experience of the MERCOSUR countries since 1991 and examine the extent to which convergence has been taking place. This is precisely the aim of the section that follows.

\section{THE REALITIES OF MERCOSUR}

We may begin with the evidence on trade integration process among the countries of MERCOSUR. Although the intra-regional trade among the 
MERCOSUR countries increased more than three times between 1991 and 2000, these countries still export, on average, less than 2.0 per cent of GDP4. Even though the trade in the region increased in the nineties, its importance compared to GDP is still very low. The trade intra-MERCOSUR is more important, however, for Uruguay and Argentina than Brazil and Paraguay (see Table 2). So, the degree of openness of the MERCOSUR countries is still low as well as the size of the economies involved to trade since their relative share in the world economy is only around 4\%. In particular, Brazil and Argentina, in spite of the recent increase in the intra-regional trade, are still very close economies in terms of international trade. Paraguay and Uruguay are more open economies, but they clearly play a very small economic role in the MERCOSUR.

Turning to capital mobility, the recent financial liberalization in the MERCOSUR area has intensified concentration in the financial markets instead of promoting competition in the national banking systems. The available evidence shows that financial liberalization, in the 1990s, has stimulated the concentration process in the financial and banking system (especially in Brazil; see, for example, Paula, 1998, Paula et al, 1999, and Meirelles, 1999). Furthermore, the institutional arrangements throughout MERCOSUR concerning the mobility of capital is quite asymmetric. Uruguay has adopted a sort of crawling peg system since the beginning of the nineties, using a band so that the currency can float with explicit linkage to price stabilisation objectives. Paraguay has recently adopted a flexible exchange rate system, and saw her exchange rate being devalued at the same time. Argentina adopted a classical currency board system since the beginning of the 1990s, pegging the peso to the dollar on a one-to-one basis, with clear stabilisation objectives. Recently, as we have already noted, the Argentine currency was devaluated and the Central Bank began to operate a floating exchange rate regime. Brazil has operated a floating exchange rate regime since the beginning of 1999 , following a period of operating a crawling peg system. There is also the important consideration that since capital flows depend on the degree of financial development, and in view of the low degree of financial deepening in the MERCOSUR countries, capital inflows are expected to be low (see Ferrari-Filho, 2002).

\footnotetext{
${ }^{4}$ In 1991 and 2000 the relation between total "fob exports" of Argentina, Brazil, Paraguay and Uruguay and total GDP of these countries was 0.80 per cent and 1.92 per cent, respectively. The intra-regional exports of MERCOSUR countries, in 1991 and 2000, represented 10.80 per cent and 20.30 per cent of total exports of MERCOSUR countries to the rest of the world, respectively. The figures just cited are own calculations from CEPAL/ECLAC (www.cepal.org).
} 
Labour mobility is relatively small within the MERCOSUR area. In particular, the mobility of labour between the two bigger countries, Brazil and Argentina, has been historically very low, and this is currently still very much in evidence. In practice, it is not difficult to demonstrate why labor mobility is relatively small, and two reasons suggest themselves: there are different technical and professional qualifications amongst the workers of the MERCOSUR countries, and labor markets in the area are regulated.

The figures cited in Tables 2 and 3 show that for the period 1991 to 2000 it is difficult to argue in favour of convergence. We comment on Table 2 and leave for later the discussion relating to Table 3. Table 2 cites data for the period 1991 to 2000 and for a number of macroeconomic variables. GDP growth rates, unemployment rates, foreign debt as a percentage of GDP, intra-MERCOSUR exports as a percentage of the aggregate of intra-MERCOSUR exports, and nominal interest rates. Taking GDP growth and unemployment rates together, Argentina and Uruguay have low growth rates (negative or zero) and high and rising unemployment rates. By contrast, Brazil and Paraguay enjoy positive and, in the year 2000 , healthy growth rates, and relatively low unemployment rates (in the case of Brazil this rates falls slightly in 2000). The evolution of these variables during the nineties shows a disparity between Argentina and Uruguay on the one hand, and Brazil and Paraguay on the other, both in terms of GDP growth and rate of unemployment. MERCOSUR economies also exhibit a high degree of volatility in terms of these variables, indicating that they are subject to substantial shocks. This seems to suggest that there are asymmetric cyclical conditions in the economies of the region, and the magnitude of the co-movement of their business cycles is small, a suggestion that is supported by Valdovinos (2000) for a longer period. $^{5}$

High foreign debt to GDP ratios are reported for all countries, but these are nearly twice as high in the case of Argentina and Brazil. Intra-MERCOSUR exports as a percentage of total exports have been decreasing since 1997. Nominal interest rates present an interesting picture. They tend to fall over the period, but they are extremely high in Brazil over the period 1991-1994, with a substantial drop in 1995 following the sharp decrease in inflation with the introduction of a price stabilisation programme (known as the Real Plan). By 1998, though, and following the Russian crisis, interest rates rise in Argentina, Brazil and Paraguay (only to fall again in 1999 in Brazil and Paraguay), but continue to fall in Uruguay.

\footnotetext{
${ }^{5}$ In this particular context, the theory of OCA shows that the greater the asymmetry of output movements, the higher the value placed on changes in the exchange rate as an instrument of relative price adjustment.
} 
An interesting pattern emerges. Argentina is a low interest rate country, while Brazil and Paraguay are relatively high interest rate countries. Uruguay is in an in-between situation. On the whole, Table 2 suggests that convergence amongst the MERCOSUR countries does not appear to be in sight.

Macroeconomic convergence targets were approved in the year 2000 by the Presidents of the MERCOSUR countries. Giambiagi (1999) also suggested similar targets. Both sets of proposals can be put together and summarized as follows. Member countries, and any other South American countries aspiring to join MERCOSUR, would be required to adhere to the following: (i) a free trade area should be created; (ii) member countries would have to harmonize their criteria for defining and measuring the principal macroeconomic variables; (iii) member countries should not devalue their currencies and they would have to maintain their exchange rates within the margins to be determined; (iv) the annual inflation rate in a specific country should not exceed 3.0 per cent; (v) any member country's budget deficit should not exceed 3.0 per cent of GDP; (vi) the net public sector debt of any member country of MERCOSUR cannot exceed 40.0 per cent of GDP; and (vii) member countries should not have excessive current account deficits, where a maximum of 3.0 per cent of GDP was thought appropriate.

We may begin our commentary with the first point, the creation of a free trade area. MERCOSUR is far away of creating a free trade area due to trade conflicts, basically, between Argentina and Brazil. Giambiagi (1999), for instance, argues that there is a deterioration in trade relations within the MERCOSUR area: "problems such as those that affected the sugar sector in Argentina, or the protest against Brazilian phytosanitary controls ... [A]fter the devaluation of the real, Argentine producers made ... demands, such as the introduction of a specific tariff against Brazilian goods, safeguard measures and the establishment of quotas" (p. 20).

In terms of the criteria for defining and measuring the principal macroeconomic variables and the maintenance of a more stable exchange rate, despite some attempts at harmonizing the main macroeconomic variables, at least now, no more progress can be reported. As for a stable exchange rate region, this may be difficult to achieve in view of the fact that Brazil and Argentina, the most important partners of MERCOSUR, until recently, had different monetary and exchange rate regimes. Even though the exchange regimes of the MERCOSUR countries differ a little among themselves, it will be difficult to adopt some plan of macroeconomic co-ordination and eventually a monetary union. Moreover, it is important to stress two points: on the one hand, the sharp and quick devaluation of the Brazilian real, in 2001 of around 20.5 per cent, created serious difficulties between Brazil and Argentina, since the latter could not devalue its currency to compensate for the movements of the real. On the other hand, 
after devaluing its currency, in January 2002, Argentina witnessed an overshooting exchange rate process. The dollar-peso was on a one-for-one basis at the beginning of 2002; one month and half later, it had jumped to 2.0 pesos per dollar. Thus, the new exchange rate and monetary regime in Argentina will bring some macroeconomic instability to MERCOSUR, at least in the near future. In other words, the different monetary and exchange rate regimes in these countries can be very disruptive. Fanelli (2000) puts it aptly when he argues that "it is almost impossible to imagine that countries adopt macroeconomic co-ordination ignoring completely the existing type of exchange rate regime" (p. 3 ; original in Spanish).

The experience of the fixed rate regime which tied the Argentine peso on a one-for-one basis with the dollar provides a warning of the consequences of a monetary union between countries with different economic circumstances and policies and without the structure for the coordination of economic policies. The peso-dollar link was entered on a unilateral basis for Argentina and, unlike the full monetary union of EMU under the euro, it was reversible (as the Argentine crisis of January 2002 shows). But that peso-dollar experience serves to illustrate the difficulties which arise from lack of similar inflationary conditions and the deflationary effects which can result from a poorly designed (quasi) monetary union. Our analysis in section IV, Lessons for Mercusor, is pertinent in this context.

We may concentrate on Table 3 to assess the rest of the conditions referred to above. Concerning the inflation rate target, despite the substantial reduction in the inflation rates in Argentina, Brazil, Paraguay and Uruguay, especially since 1998, these countries still have inflation rates above the 3.0 per cent threshold, with the exception of Argentina which has had an inflation rate under 3.0 per cent since 1995. However, the ceiling of 3 per cent of inflation for each country may be too ambitious if one considers the high past inflation rates in the countries of the region. Argentina is the only country that had in the second half of the nineties an inflation rate below 3 per cent, but this was only possible with the adoption of an extremely rigid currency board regime. But then Argentina is the country with the highest rate of unemployment in the MERCOSUR area (see Table 2).

The figures for the fiscal deficits in MERCOSUR countries show that (a) the fiscal deficit in Brazil, since 1995, has been greater than 3.0 per cent of GDP; (b) Argentina's budget deficit, between 1991 and 2000, was always less than the target established; and (c) fiscal deficits in Paraguay and Uruguay have been less than 3.0 per cent of GDP throughout except for 2000 and 1999 and 2000, respectively. In terms of the ratio of public sector debt to GDP we may observe that: (a) in the case of Paraguay over the period 1991 and 2000, it has been less 
than 40.0 per cent, although it has increased in the last three years; in Uruguay, from 1991 to 2000, it has been satisfied, but it has been increasing since 1999; (b) in Argentina it was greater than 40.0 per cent in 1999 and 2000; and in Brazil during the last three years, it has been greater than 40.0 per cent, and it has been increasing. Finally, looking at the figures relating to the current account deficits, it may be noted that, in 2000 , the ratio of current account deficit to GDP is above 3 per cent for Argentina and Brazil, but below it for Paraguay, and just under 3 per cent in the case of Uruguay. It is also important to note that since 1996 there has been a clear deterioration in the current account deficit of Argentina, Brazil and Uruguay, and this tendency has been followed, mainly in the case of Argentina and Brazil, by an increase in the foreign debt/GDP ratio (see Table 2). This raises an intriguing question in that given these high foreign debt to GDP ratios, the 3.0 per cent and 40.0 per cent fiscal criteria, even though they may not be so restrictive, cannot be feasible. When external pressures oblige central banks to raise sharply their interest rates, government debt would inevitably increase in view of the short-term maturity of securities in the MERCOSUR area.

We may summarise by suggesting that the attempt to create a MERCOSUR regional monetary union is open to a number of objections: first, the MERCOSUR's factor markets are not sufficiently unified to make it an optimum currency area; second, the volume of intra-regional trade among the MERCOSUR countries is still low; and the macroeconomic variables in the proposed union show that there is a long way to go before convergence is achieved. We thus concur with Eichengreen (2000) that MERCOSUR countries do not appear to satisfy the preconditions for a monetary union.

\section{SUMMARY AND CONCLUSIONS}

We have argued in this paper, that the use of the EMU model of monetary union implies adopting a deflationary policy. Since the countries of MERCOSUR have more social problems than the countries of the EU, the cost of adopting a MERCOSUR monetary union on the Euro pattern would probably be greater than in the case of the EU. It would be necessary to have much more flexible mechanisms of compensation in terms of fiscal transfers in order to tackle the socio-economic problems of the MERCOSUR countries. This would be difficult even in the medium to long run if one considers the magnitude of the fiscal problems in the MERCOSUR countries. Consequently, the first lesson that can be extracted from the EMU experience is to avoid using this model as the benchmark for a possible MERCOSUR monetary union. 
Our analysis also shows that there is no evidence that macroeconomic convergence is evident in MERCOSUR. The area has only minimally achieved some basic criteria defined by the OCA literature, and as Eichengreen (2000) argues, "the list of preconditions for a single currency to operate smoothly is rather formidable, and it is not clear that the members of MERCOSUR union are prepared to satisfy them" (p. 19). Besides, the macroeconomic problems the MERCOSUR countries are faced with are so big that even in the long-run it is difficult to believe that some minimum convergence can be reached. A monetary union requires achieving some convergence in terms of preferences between inflation and unemployment, among other macroeconomic variables. Although the process of democracy is consolidating in the Southern countries of Latin America, they are still too far from a most balanced political system, mainly in the two bigger countries, Brazil and Argentina. Consequently, it will be difficult for the MERCOSUR countries to reach a consensus in terms of both an economic and a political agenda.

It is still too early to evaluate the effects of exchange rate devaluation in Argentina, in terms of inflation, GDP growth and balance of payments accounts, etc., since this change is very recent. Indeed, a context of macroeconomic instability is not appropriate to set up new macroeconomic convergence targets. However, it is likely that, in the future, the adoption of a floating exchange regime by Argentina may favour MERCOSUR countries to adopt more effective mechanisms of macroeconomic co-ordination.

A final comment relates to the fact that since MERCOSUR has not even reached the stage of a common market yet, it is premature to think of the countries composing it as being ready to form a monetary union. It is indeed the case that "supplementing regional integration with an initiative to stabilize the exchange rate or move toward a single currency becomes more urgent when integration moves beyond the establishment of a free trade area or a custom union to the creation of a deeply integrated market" (Einchengreen, 2000, p. 21), so that "monetary union makes sense as a solution to MERCOSUR's exchange regime rate problem only if it is part of a significantly deeper project" (op. cit., p.44). It is thus premature to discuss a MERCOSUR monetary union. Above all, however, even if the stage were reached for such a union, we would suggest that the EMU model is not appropriate for this area. 


\section{REFERENCES}

Arestis, P., Biefang-Frisancho Mariscal, I., Brown, A. and Sawyer, M. (2001a), 'The Decline of the Euro in its First Two Years: Is There a Satisfactory Explanation?', Canadian Journal of Business, forthcoming.

Arestis, P., Biefang-Frisancho Mariscal, I., Brown, A. and Sawyer, M. (2001b), 'Explaining the Euro's Initial Decline', Eastern Economic Journal, forthcoming.

Arestis, P., Brown, A. and Sawyer, M. (2001), The Euro: Evolution and Prospects, Cheltenham: Edward Elgar Publishing, forthcoming.

Arestis, P., McCauley, K. and Sawyer, M. (2001), 'An Alternative Stability and Growth Pact for the European Union', Cambridge Journal of Economics, Vol. 25, No. 1, pp. 113-130.

Cepal/Eclac (2001), http://www.cepal.org.

Edwards, S. (1998), 'How About A Single Currency to MERCOSUR?' Wall Street Journal, 28 August, p. A11.

Eichengreen, B. (2000), 'Does Mercosur Need a Single Currency?', in IPEA (ed), Mercosur and the Free Trade Areas of the Americas, Vol. 1, Brasilia: IPEA.

Fanelli, J.M. (2000), Coordinación macroeconómica en el Mercosur: marco anaíitico y hechos estilizados, Noviembre, Buenos Aires: CEDES.

Fanelli, J.M., Rozenwurcel, G. and Simpson, L. (1996). Financial liberalization in developing countries: the Argentine experience in the nineties. Buenos Aires: CEDES.

Ferrari-Filho, F. (2002), 'A Critique of the Proposal of Monetary Union in Mercosur', In: Davidson, Paul (org.). A Post Keynesian Perspective on Twenty-First Century Economic Problems. Cheltenham: Edward Elgar Publishing, pp.56-68

Financial Times (1998), 23 March.

Giambiagi, F. (1999), 'Mercosur: Why Does Monetary Union Make Sense in the Long Run?' Ensaios BNDES. 12, December, Rio de Janeiro.

Giambiagi, F. and Rigolon, F. (1999), 'Áreas Monetárias Ótimas: Teoria, Unificação Monetária Européia e Aplicações para o Mercosul', Economia Aplicada, Vol. 3, No. 1, pp. 79-99.

Inter-American Development Bank (2001), http://www.iadb.org. 
Kenen, P. (1969), 'The Theory of Optimum Currency Areas: an Eclectic View', in R. Mundell, R. and A. Swoboda (eds.), Monetary Problems of the International Economy, Chicago: University of Chicago Press.

McKinnon, R.I. (1963), 'Optimum Currency Areas', American Economic Review. Vol. 53, No. 4, pp. 717-25.

Meirelles, A.C. (1999), 'Tamanho É Documento na Competição Bancária'. Fórum de Lideres/Gazeta Mercantil', Vol. 1, No. 1, pp. 54-72.

Mercosul (2001), http://www.mercosul.org.

Mundell, R.A. (1961), 'A Theory of Optimal Currency Areas', American Economic Review, Vol. 53, No. 1, pp. 657-664.

Paula, L.F.R. (1998), 'Tamanho, Dimensão e Concentração do Sistema Bancário no Contexto de Alta e Baixa Inflação no Brasil', Nova Economia, Vol. 8, No. 1, pp. 87-116.

Paula, L.F.R., Sobreira, R. and Zonenschain, C.N. (eds), (1999), Perspectivas para o Sistema Financeiro Nacional: Regulação do Setor e Participação do Capital Estrangeiro, Universidade Candido Mendes-Ipanema: Rio de Janeiro.

Pentecost, E.J. (1999), 'Monetary Unions in Nineteenth Century Europe: An Historical Perspective and Lessons for EMU in the Twenty-first Century', in S. Daniel, P. Arestis and J. Grahl (eds), The History and Practice of Economics, Essays in Honour of B. Corry and M. Peston, Vol. 2, Cheltenham: Edward Elgar Publishers.

Valdovinos, C.G.F. (2000), 'Cyclical Co-Movements in Output Across MERCOSUR Countries', http://www.bcp.gov.py/GEE/investman/carlos/cyclical.htm. 
TABLE 1- MONETARY UNIONS

STILL SURVIVING BUT WITH POLITICAL UNION

British monetary union between England and Scotland

From 1707

Italian monetary union

From 1861

US Federal Reserve system

From 1913

German unification

From 1990

STILL SURVIVING WITHOUT POLITICAL UNION

Belgium - Luxembourg union

From 1923

West and Central African CFA Franc Zone ${ }^{a}$

From 1948

Eastern Caribbean Currency Union ${ }^{\mathrm{b}}$

From 1983

FAILED ONCE POLITICAL SYSTEM COLLAPSED

Roman monetary union

286-301

German monetary union

1857-1918

The Soviet system

1917-1993

Yugoslavia

1919-1992

Czechoslovakian Republic

1919-1994

FAILED ONCE ECONOMIC LINKS COLLAPSED

British Monetary Union Between England and Ireland 1926-1979

TEMPORARY MONETARY UNIONS

\begin{tabular}{ll}
\hline Latin Monetary Union $^{\mathrm{d}}$ & $1865-1926$ \\
Scandinavian currency union $^{\mathrm{e}}$ & $1873-1921$
\end{tabular}

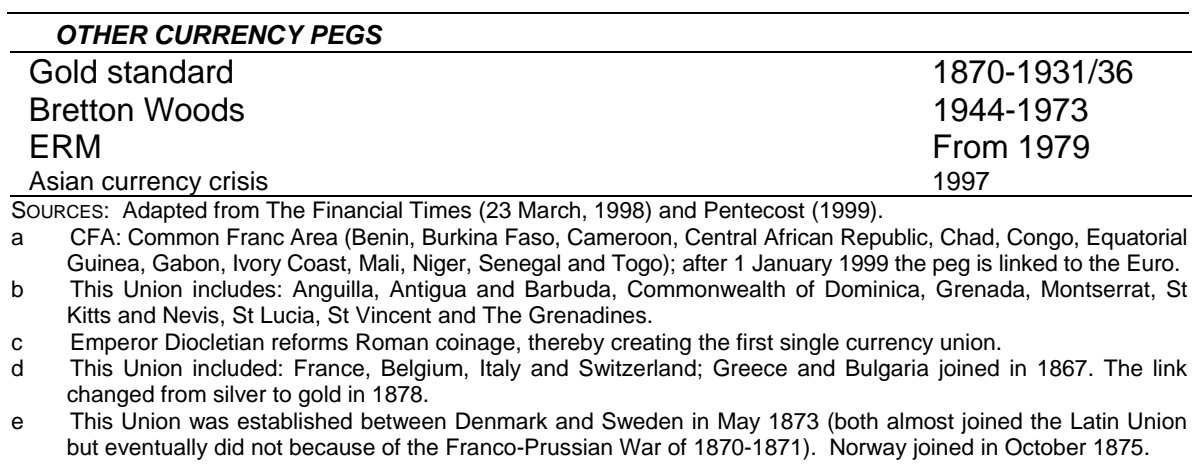


The euro and the EMU...

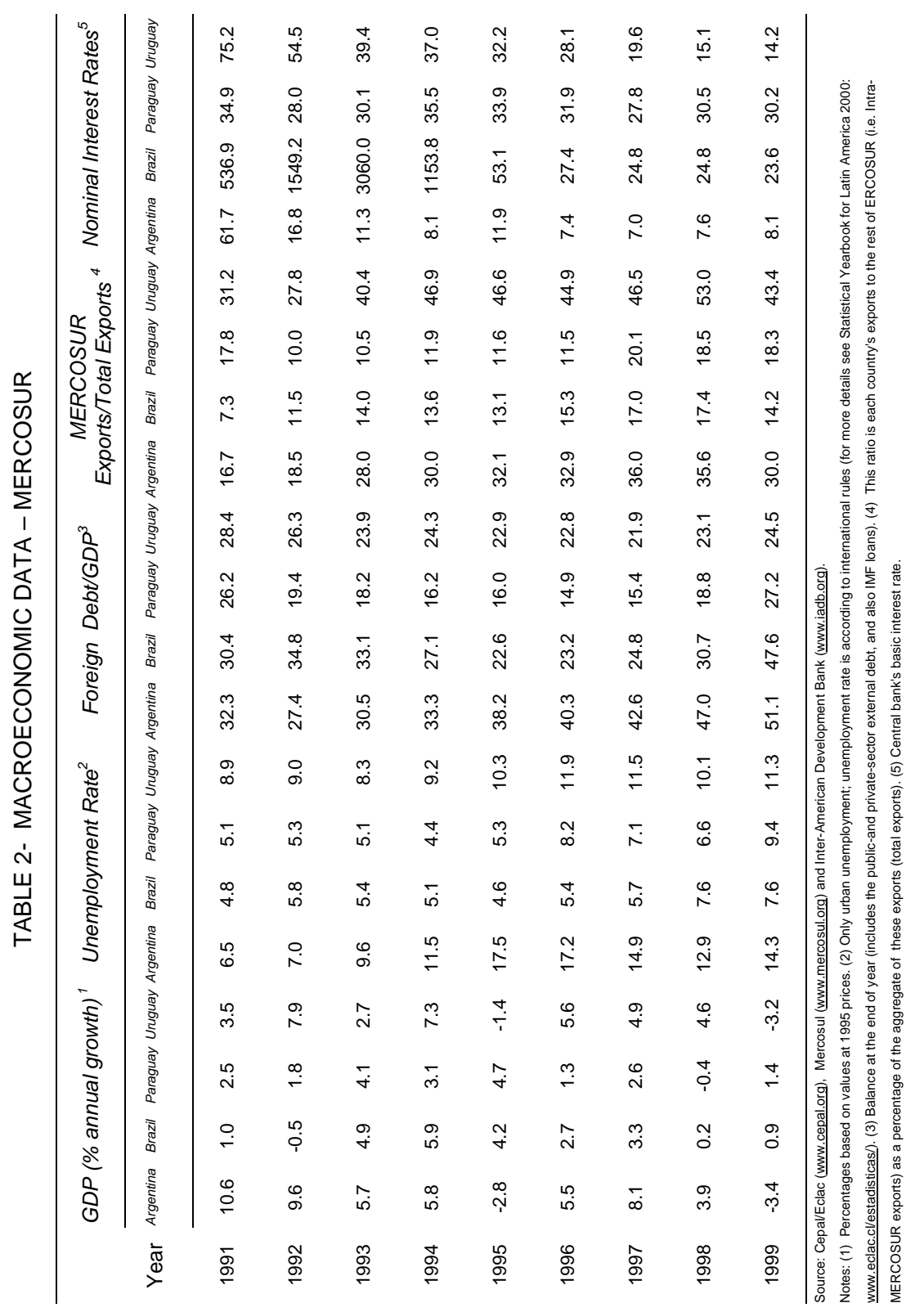


